症例

肺部分切除が妥当であった自動草刈り機による肺切創の 1 例

\begin{tabular}{|c|c|c|c|c|c|c|c|c|c|}
\hline \multicolumn{10}{|c|}{ 小諸厚生総合病院外科 } \\
\hline 山 & 敏 & 之 & 高 & 田 & 学 & 佐 & 近 & 雅 & 宏 \\
\hline 秋 田 & 真 & 吾 & 小 & 松 信 & 男 & 橋 & 本 & 曋 & \\
\hline
\end{tabular}

症例は74歳, 男性. 鉄道沿線の草刈り作業中, 他の人の自動草刈り機の刚刃が背部に 接触し外傷を負ったため, 救急車で当院に搬送された. 創は長さ $25 \mathrm{~cm}$ にわたり筋肉, 肋 骨が切断され胸腔内に到達しており創から左肺が観察された。ただちに全身麻酔下に手 術を行い胸腔内の観察を行ったところ，心・大血管の損傷はなかったが，左肺下葉（S6） に幅 $8 \mathrm{~cm}$, 深さ $2 \mathrm{~cm}$ の損傷を諗めた. 自動縫合器を用いて同部を切除・縫合し, 胸腔 内および胸壁創を充分洗浄したのち閉胸，手術を終了した。経過は良好で術後10日で退 院した。

索引用語：自動草刈り機, 鋭的胸部外傷

はじめに

自動草刈り機の刚刃が直接人体に接触し傷害を引き 起こす場合は四肢の受傷がほとんどで')，刈刃が体幹 に接触して深部内蔵を損賃したという報告は極めて稀 である. 今回われわれは草刈り機による鋭的穿通性胸 部外傷の１例を経験し手術する機会を得たので報告す る.

症例：74葴, 男性.

\section{症例}

主訴：背部痛, 呼吸苦。

既往歴：60歳, 胃癌に対して胃严全摘術。

家族歴：特記事項なし.

現病歴：2002年 8 月 7 日午前11時頃，鉄道沿線の草 刈り作業をしていたところ，他の人が作業中の草刘り 機の回転中の刚刃が左背部に接触したため救急車で当 院に搬送された。

入院時現症ならびに検查所見：意識清明，血圧140/ $80 \mathrm{mmHg}$, 脈拍60/分, 整. 背部正中やや右側から左後 盿窝線に向かう直線的な長さ $25 \mathrm{~cm}$ の切硘を認めた。 創は刃物によるもののように鋭利で皮成，筋肉および 肋骨を切断し胸腔内にまで至り，創部から直接左肺が 観察可能であった。 4 L の酸素投与で血中酸素飽和度

2002年 9 月 24 日受付 2002 年11月28日採用 〈所属施設住所〉

$\overline{\mathbf{T}} 384-0006$ 小諸市与良町 $3-2-31$
（Spo2）は96〜98であった。血液生化学的検査では LDH 46.5, CPK 414と軽度上昇している以外に異常を 諗めなかった。

胸部 CT 写真：筋性胸壁枋よび骨性胸壁とも切開さ れ開放性気胸の状態となっており，左肺は縮小しかつ S6 を中心に肺挫傷によると思われるすりガラス状陰 影を認めた（図 1 ).

入院後経過：胸壁損傷ならびに肺損傷の診断でただ ちに手術を行った．全身麻酔下に創部を観察したとこ ろ，創には胁骨の破片とともに草や砂などの異物が多 数付着しており皮阔, 筋肉の切開創と同じレベルで左 第 8 肋骨は長軸方向に部分的に削り取られるように切 断され第て助閥で開胸されていた。胸腔内には少量の 血液眝留か認められたが，心䑏や大血管の損偒は認め られなかった。次いで肺を観察したところ左肺下葉 S6

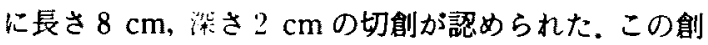
も非常に鋭利な刃物で切開したかのような創であり空 気漏出は認められたものの出血はごくわずかであった

(図 2 ). 単純綎合閉鎖では術後に感染が生じる可能性 があると判断し，自動縫合器を用いて肺損傷部を含め て左下肺を部分切除した。出血, 空気漏出のないこと を確認したうえで，生理食塩水により胸腔内および胸 壁創部を允分に洗浄した姼、ドレーンを留置し閉胸, 手術を終了した。結性的に自動草刈り機の刈刃は，左 第 8 肋骨を長軸方向に切断しそのまま第 7 肋間から胸 驾内に到達し左肺のS6部を損鹪したものと考えられた。 

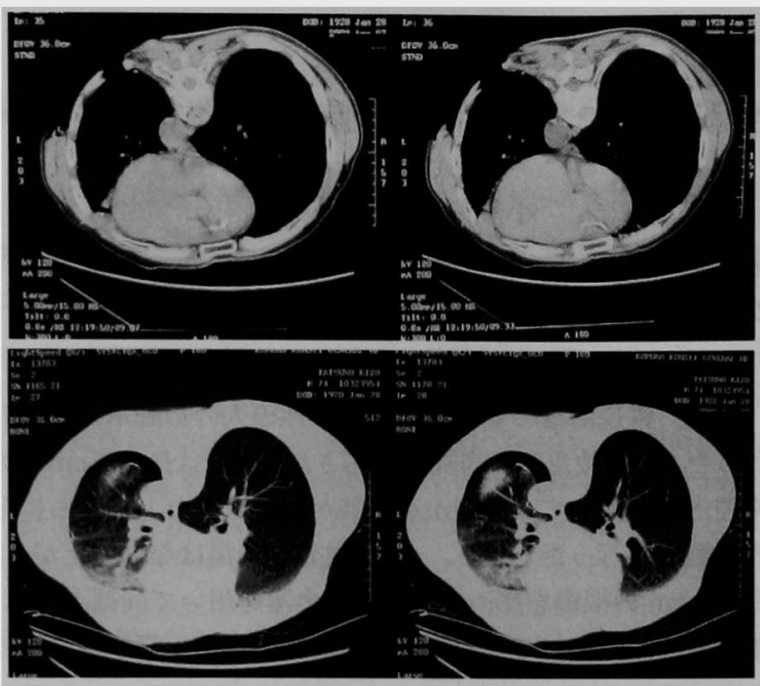

图 1 胸部 CT 写真(水平面)：左肺は縮小し，S6 を中心に肺挫 侮と思われるすりガラス状陰影を訊めた。 大血管の損傷はな く，胸腔内には血液の貯留はほとんど認められなかった。
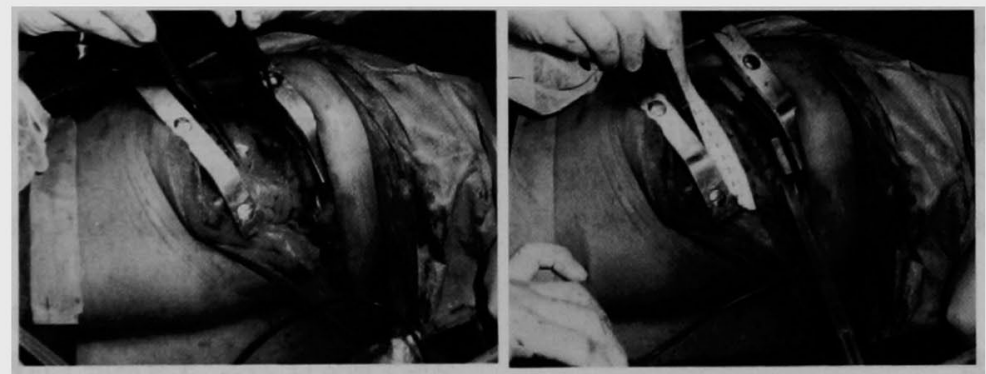

图 2 術中生体写真：左肺下葉 $\mathrm{S} 6$ に長さ $8 \mathrm{~cm}$, 深さ $2 \mathrm{~cm}$ の切創が認められ た.この㓱も胸壁の創と同様に非常に鋭利な刃物で切開したかのような創であ り空気漏九は訆められたものの出血はごくわずかであった。

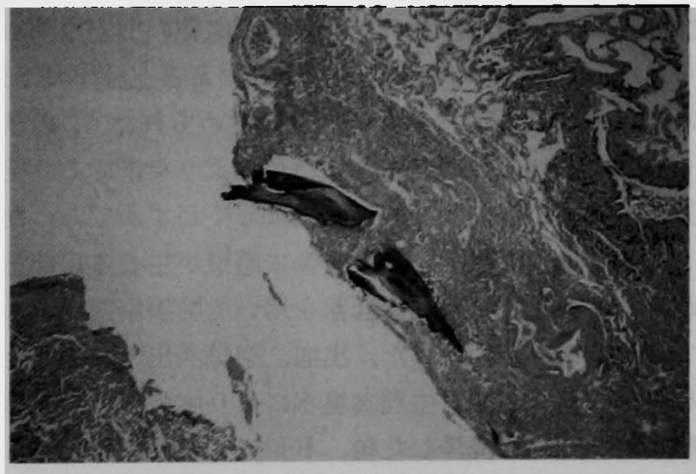

图 3 病理組織学的所見 (HE 染色, $\times 40)$ ：肺胞内, 間質 に出血が認められ，所々に肋骨の切り屏と思われる贯 片組織が埋没していた。
切除標本：受儌肺は肺胞内, 間質に出血が認められ, 所々に肋骨のものと思われる骨片が肺組織内に伏埋さ れていた（図3).

術啳経過：大きな合併症もなく,術後10日で退院した。 外靎の原となった草刈り機：全長 $1 \mathrm{~m} 67 \mathrm{~cm}$, 重量 $6.8 \mathrm{~kg}$ の肩掛け式,両手ハンドル型の草刈り機で,作業 時には小型発動機を動力として直径10インチ（25.5 $\mathrm{cm}$ ）の丸鋸型の刚刃が毎分5,000〜7,000回（最高 8,000 ) 回転し草や小枝を切る構造になっている(図4).

\section{考察}

草刈り機は本邦において1940年代から主に林業て使 用されるようになり，1970年代に入ってから一般の農 作業などにも使用され普及しはじめた2). 1980年代後 


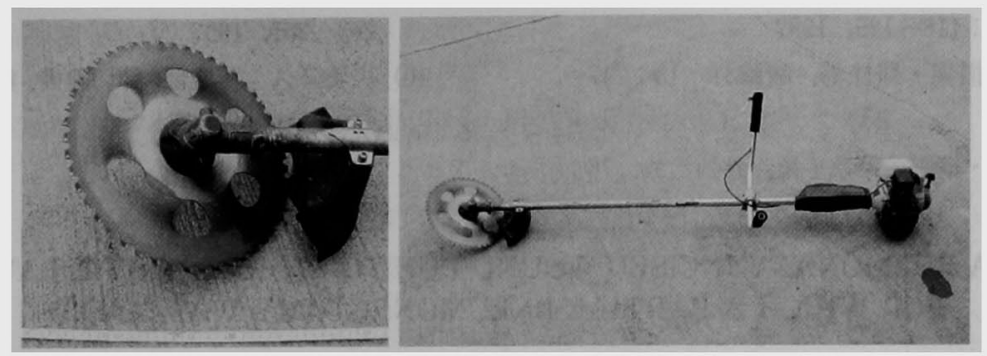

図4外俉の原因となった草刚り機：全長 $1 \mathrm{~m} 67 \mathrm{~cm}$, 重量 $6.8 \mathrm{~kg}$ の肩掛け式, 両 手ハンドル型の草刈り機で, 作業時には小型発動機を動力として直径10インチ

(25.5cm) の丸鋸型の刚刃が毎分5,000 7,000回（最高8,000）回転し草や小 枝を刈り取る榑造になっている.

半までに既に300〜400万台が販売されており り2，現在 ではホームセンターなどで一般の人でも容易に入手可 能である。

自動草刈り機の普及に伴いその使用中に生じた様々 な外偒が報告されている. 草刈り機作業中の外傷の原 因としては(1)回転する刈刃の破片または刈刃にはね飛 ばされた物体が飛来して人体を傷害する，(2)回転する 刈刃そのものが人体に接触して人体を傷害する，の 2 つに大別される．回転する刈刃によって発生した飛来 物体が人体を偒害する代表例は穿孔性眼外傷であ $\eta^{223)}$ 自動草刚り機の普及とともに穿孔性眼外傷の主 な原因となっている。

刚刃が直接人体に接触し傷害を引き起こす場合は四 肢の受偒がほとんどで1)，刚刃が体幹に接触して深部 内茐を損傷したという報告は極めて稀である，涉猟し た限りてはわれわれの報告は, 刈刃が右背部に接触し, 胸壁を穿通し右肺下葉 (S10) から右横隔膜にまで損賃 が及んでいたという小延ら”の報告に次いで本邦 2 例 目である。

従来, 外鹪性肺損䂓に対してはその程度および籍囲 によって単純繾合, 部分切除, 葉切除などが適宜選択 施行されている を行うと後に肺晨瘍や無気肺などの合併症を生ずるこ とがあり，肥後ら゙は，その比率が51\%と予想外に高か つたと報告している。特に，鋭的穿通性胸部外傷によ る肺損鹪では鈍的非穿通性胸部外傷による肺損傷に比 へ肺損傷部の細菌污染の可能性が高くなる5).

われわれの症例では切除標本において助骨由来と思 われる骨片が肺創面に伏埋されていた。これは草刈り 機の刚り刃が，回転しながら刈り刃のみぞに入り込ん だ物体を創面に伏埋しつつ組織を切開していくためで
あり，自動草刈り機による創の特徵と考えられる.肺 創面には骨片のみならずそれ以前に刈った草や小枝な どの異物も伏埋されていたと思われ，単純絴合のみて は肺膿瘍などの感染症を惹起する危険がある。これを 防ぐためには，肺切創に対して深い連続縫合を置き， 肺創面を外反 (外化) させドレーンを長めに留置する という方法も考えられるが，われわれは自動吻合器を 用いて感染巣となりえる部を可及的に切除すると同時 に止血と空気漏出の閉鎖を行った．自動吻合器の使用 は健常組織を檥性にする，高価である，などの難点が あるが9，簡便で手術時間も短縮されかつ信頼性もあ るので外傷性肺損賃, 特に穿通性胸部外傷の際の肺損 傷に対しては積極的に試みてよい方法と思われた。

\section{文献}

1）日本農村医学会：農業機械に起因する災害(外賃) の臨床的調査 (昭和50年). 日農村医会誌 $26: 117$ $-146,1977$

2）木村㹂二郎：動力草刈り機による眼外鹪。眼科 $29: 783-788,1987$

3）相馬信和, 生島 操, 兵頭靖秋他：草刈り機使用 による穿孔性眼外傷の娭討。眼臨医報 $92: 604-$ 608, 1998

4）小延俊文, 畑 倫明, 今西正巳他：胸部 $X$ 線上て 異常を認めなかった鋭的外賃による肺・獚隔膜損 偈の 1 例. 胸部外科 $53: 1049-1051 ， 2000$

5）門田康正：肺・気管・気管支損鹪. 新外科学体系, 第16巻 B，中山卷店，東京，1989，p53-65

6）肥後 孝, 葛西 猛, 広沢那浩 他：外傷性肺損鹪 に対する肺切除術の適応と術後の問題点につい

て。 日外鹪研会誌 $4: 251-256,1990$

7）益子邦洋, 小関一英, 加藤一良他：最近の胸部外 
傷. 外科 $54: 118-125,1992$

8）暮西 猛：肺損傷・眠挫傷. 臨胸外 $13: 247-$ 250, 1993
$263-267,1997$

10）川嶋隆久：肺縫合, 肺切除術. 救急医 $23: 545-$ 550,1999

9）今井 寬：肺・縦滆の緊急手術. 外科治療 76 ：

\title{
A CASE OF A PULMONARY INCISED WOUND DUE TO AN AUTOMATIC LAWN MOVER FOR WHICH A PARTIAL PNEUMONECTOMY WAS SOUND
}

\author{
Toshiyuki YAMAGUCHI, Manabu TAKADA, Masahiro SAKON, \\ Shingo AKITA, Nobuo KOMATSU and Shin-ichi HASHIMOTO \\ Department of Surgery, Komoro Koseiren General Hospital
}

A 74-year-old man, who suffered injury to his back in minor collision with an automatic lawn mover driven by other person during mowing along the reilway, was brought into the hospital by ambulance. The wound was $25 \mathrm{~cm}$ in length and reached to the thoracic cavity, at where the muscles and ribs were cut. The left lung was observed through the wound. We initiated an emergency operation under general anesthesia and observed the thoracic cavity. There were no injuries to the heart and large vessels, but an injury with the width of $8 \mathrm{~cm}$ and depth of $2 \mathrm{~cm}$ was present in the left lower lobe of lung (S6). The injury was resected and sutured by using as automatic suture machine, and the opened chest was closed after sufficient levage of the thoracic cavity and chest wall wound. The postoperative course was uneventful and the patient was discharged from the hospital on the tenth postoperative day. 